\title{
Application of Clean and Healthy Living Behavior (PHBS) From The Household Knowledge and Attitude Study
}

\author{
Ronasari Mahaji Putri, Yanti Rosdiana, Aprilia Choirun Nisa \\ Faculty of Health Sciences, Tribhuwana University Tunggadewi, Malang, Indonesia \\ Corresponding author: putrirona@gmail.com
}

\begin{abstract}
Background: The behavior of clean and healthy life (PHBS) is an obligation to be carried out by everyone. PHBS is an effort to maintain the health of themselves and their families. The PHBS coaching program has been running for approximately 18 years, but its success is far from expected. It is necessary to explore the factors underlying the failure to implement PHBS. Mothers as educators in the family, have an obligation not only to implement PHBS for themselves, but also educate their children to conduct clean and healthy lifestyle.
\end{abstract}

Purpose: This study aimed to determine the application of clean and healthy behavior (PHBS) from the study of knowledge and attitudes of housewives in the household setting.

Method: This research is a descriptive study with a cross sectional approach, involving 39 housewives in RT 03 RW 06 Tlogomas Malang. The sample is taken in total side. The independent variable is the knowledge and attitudes of housewives, while the dependent variable is clean and healthy living behavior. Instrument to explore knowledge, attitudes and behavior using a questionnaire. Data analysis using the Spearman rank test.

Result: The results showed that as many as $43.6 \%$ of housewives were well informed, $76.9 \%$ of housewives had good attitudes, and as many as $69.2 \%$ of mothers had good PHBS. Statistical tests show there is no relationship between knowledge with PHBS ( $p$ value 0.792), and there is a relationship between attitudes and PHBS of housewives (pvalue 0.007 ).

Conclusion: The application of clean and healthy lifestyle is not related to knowledge, but is related to the attitude of housewives in RT 03 RW 06 Tlogomas Malang.

Keyword : Mother, Implementation, Clean and Healthy Behavior, Knowledge, Household

Received July, 29, 2019; Revised August 30, 2019; Accepted September 22, 2019

How to Cite: Putri, R.M., Rosdiana, Y., \& Nisa, A.C. (2019). Application of Clean and Healthy Living Behavior (PHBS) From The Household Knowledge and Attitude Study. Journal Of Nursing Practice, 3(1), 39-49. https://doi.org/10.30994/jnp.v3i1.64 


\section{BACKGROUND}

Family is the smallest unit of a society. Various efforts will certainly always be carried out by the family, including in terms of health, with the aim that family life can live a healthy and happy life. Clean and Healthy Life Behavior (PHBS) is an obligation to be carried out by everyone. PHBS is an effort to maintain the health of themselves and their families. Rahmawati (2012) revealed that PHBS is an effort to make family members want and be able to act clean and healthy lives and play an active role in the movement of healthy living. The efforts carried out and expected from this clean and healthy lifestyle are in accordance with the health development mission in the range of 2015-2019, namely the Indonesia Program through improving health status, nutritional status with various efforts carried out and by empowering communities and supporting financial protection and providing health services evenly (Indonesia, 2014). The PHBS coaching program has been running for approximately 18 years, but its success is far from expected (Dinas Kesehatan Lumajang, 2015). There are still many housewives who have PHBS less. Data shows that in East Java $48.3 \%$ have good households, but this figure is still far from the $70 \%$ target (Indonesia, 2014). Data (Kemenkes, 2018), it is known that from 38 regencies / cities in East Java, 33 districts / cities were found with PHBS policies reaching 86.84\%; 9 regencies / cities from 38 districts / cities have implemented at least 5 themes of the Community Life Movement campaign.

The implementation of PHBS in the household is not only the responsibility of the household, but the importance of each family member making this PHBS effort. Noncompliance of one family member in carrying out PHBS indirectly will cause the emergence of infectious and non-infectious diseases. Can be said so, because family members who do not run PHBS will be at risk for experiencing greater disease than family members who implement PHBS. With one family member suffering from illness, it will facilitate the transmission of the disease in one family. If the PHBS business is carried out perfectly (in 10 indicators), it will reduce the incidence of undesirable diseases more or less. From the description above, it can be said that the beh(Hidayat, TS dan Faudia, 2011)avior of clean and healthy living is a way to prevent the entry of diseases into the body. Slamet (2002) confirming that the implementation of PHBS in a family or individual that is less likely to cause the body to contract the disease according to his lifestyle, also concluded that the level of poor health causes nutritional problems for individuals or families. agree with research (Hidayat, TS dan Faudia, 2011), that healthy environmental sanitation is related to the nutritional status of children under five (BB / U).

Mothers as educators in the family, have an obligation not only to implement PHBS for themselves, but also educate their children to conduct clean and healthy lifestyle. Various activities carried out by the mother, really took the attention and energy of housewives. Starting from housework to caring for children and husbands, the point is to complete the work in the house. The busyness of housewives will increase without any help from other people (domestic helpers). Housewives can easily experience stress if they do not have a good coping mechanism. In accordance with the Putri,KAK., Sudhana (2013) who concluded that there was a difference in stress between housewives without help compared to mothers who used helpers (pvalue=0,00). As a result, if the mother experiences stress, the mother cannot carry out and complete household work, including not being able to do PHBS. PHBS housewives can run well, if the mother has good knowledge and attitude about the implementation of PHBS. This study aims to determine the relationship between knowledge, attitudes and hygiene behavior in housewives RT 03 RW 06 Malang Tlogomas 


\section{Journal Of Nursing Practice}

http://thejnp.org

ISSN: 2614-3488 (print); 2614-3496 (online)

Vol.3 No.1. October 2019. Page.33-49

\section{OBJECTIVE}

This study aimed to determine the application of clean and healthy behavior (PHBS) from the study of knowledge and attitudes of housewives in the household setting.

\section{METHODS}

This research is a descriptive study with a cross sectional approach, involving 39 housewives in RT 03 RW 06 Tlogomas Malang. The sample is taken in total population. The independent variable is the knowledge and attitudes of housewives, while the dependent variable is clean and healthy living behavior. Instrument to explore knowledge, attitudes and behavior using a questionnaire. Data analysis using the Spearman rank test.

The participants were assured that their engagement was voluntary, and that anonymity, privacy, and confidentiality of the data were guaranteed. Furthermore, they were informed about the purpose and the method of the study before signing a written informed consent. The questionnaires were distributed to eligible participants at the Tlogomas Malang, and respondents were asked to complete and return them in the same time

\section{RESULTS}

Tabel 1 Frequency Distribution of Respondents Based on Characteristics of Housewives in RT 03 RW 06 Tlogomas Malang

\begin{tabular}{lcc}
\hline Age (years) & Total & $\%$ \\
\hline $26-35$ & 10 & 25,6 \\
$36-45$ & 19 & 48,7 \\
$46-55$ & 5 & 12,8 \\
$56-65$ & 3 & 7,7 \\
65 and above & 2 & 5,1 \\
\hline Mother's work & Total & $\%$ \\
\hline Work & 9 & 23,1 \\
Not Work & 30 & 76,9 \\
\hline Mother's education & & \\
\hline Elementary scholl & 10 & 25,6 \\
Junior Hig Scholl & 9 & 23,1 \\
High School & 16 & 41 \\
S1 & 4 & 10,3 \\
\hline Family Income & & \\
\hline$<2$ jt & 25 & 64,1 \\
$>$ 2jt & 14 & 35,9 \\
\hline Get Counseling & & \\
\hline Yes & 22 & 56,4 \\
No & 17 & 43,6 \\
\hline Jamkesmas Ownership & & \\
\hline Yes & 26 & 66,7 \\
No & 13 & 33,3 \\
\hline
\end{tabular}




\section{Journal Of Nursing Practice}

http://thejnp.org

ISSN: 2614-3488 (print); 2614-3496 (online)

Vol.3 No.1. October 2019. Page.33-49

Based on Table 1 it is known that as many as 48.7 respondents aged $36-45$ years; $76.9 \%$ of mothers do not work; $41 \%$ of mothers have high school education; $35.9 \%$ of mothers have family income> 2 million; $56.4 \%$ of mothers get counseling about PHBS; as many as 25.6 mothers have elementary education; $66.7 \%$ had leadership in Jamkesmas.

From Table 2, it is known that most housewives have PHBS knowledge in sufficient categories, namely 17 people $(43.6 \%)$.

Tabel 2 Respondent Frequency Distribution Based on Knowledge of Housewives About the Application of Clean and Healthy Behavior (PHBS) in RW 06 Tlogomas Malang

\begin{tabular}{lcc}
\hline Criteria & Total & $\%$ \\
\hline Well & 14 & 35,9 \\
Enough & 17 & 43,6 \\
Less & 8 & 20,5 \\
\hline Total & 39 & 100 \\
\hline
\end{tabular}

Tabel 3. Respondents' Frequency Distribution Based on the Attitudes of Housewives About the Application of Healthy and Healthy Life Behavior (PHBS) in RW 06 Tlogomas Malang

\begin{tabular}{lcc}
\hline Criteria & Total & $\%$ \\
\hline Well & 30 & 76,9 \\
Enough & 3 & 7,7 \\
Less & 6 & 15,4 \\
\hline Total & 39 & 100 \\
\hline
\end{tabular}

From Table 3 it is known that most housewives have a good attitude about PHBS, which is 30 people $(76.9 \%)$.

Tabel 4. Respondents 'Frequency Distribution Based on Housewives' Behavior About the Application of Healthy and Healthy Life Behavior (PHBS) in RW 06 Tlogomas Malang

\begin{tabular}{lcc}
\hline Criteria & Total & $\%$ \\
\hline Well & 27 & 69,2 \\
Enough & 4 & 10,3 \\
Less & 8 & 20,5 \\
\hline Total & 39 & 100 \\
\hline
\end{tabular}

From Table 4 it is known that most housewives have good behavior about PHBS, which is 27 people $(69.2 \%)$. 


\section{Journal Of Nursing Practice}

http://thejnp.org

ISSN: 2614-3488 (print); 2614-3496 (online)

Vol.3 No.1. October 2019. Page.33-49

Table 5. Cross Tabulation of Knowledge and Behavior of Housewives Regarding the Application of Healthy and Behavior (PHBS) in RW 06 Tlogomas Malang

\begin{tabular}{lllll}
\hline Knowledge & \multicolumn{2}{c}{ Perilaku } & Total \\
\cline { 2 - 4 } & \multicolumn{2}{c}{ Well } & Enough & Less \\
\hline Well & 9 & 2 & 3 & 14 \\
Enough & 14 & 2 & 1 & 17 \\
Less & 4 & 0 & 4 & 8 \\
\hline Total & 27 & 4 & 8 & 39 \\
\hline
\end{tabular}

From Table 5 it is known that housewives who have sufficient knowledge will have an impact on good behavior by 14 people; and knowledgeable mothers will have an impact on PHBS behavior that is less than 3 people.

Table 6. Cross Tabulation of Attitudes and Behavior of Housewives About the Application of Healthy and Behavior (PHBS) in RW 06 Tlogomas Malang

\begin{tabular}{lcccc}
\hline & \multicolumn{3}{c}{ Behavior } & \multicolumn{2}{c}{ Total } \\
\cline { 2 - 4 } Attitude & Well & Enough & Less & \\
\hline Well & 23 & 3 & 4 & 30 \\
Enough & 2 & 1 & 0 & 3 \\
Less & 2 & 0 & 4 & 6 \\
\hline Total & 27 & 4 & 8 & 39 \\
\hline
\end{tabular}

From Table 6 it is known that mothers who have a good attitude, will behave well as many as 23 respondents; however, mothers who behave well also cause the formation of PHBS behavior that is less than 4 people.

The results of statistical tests using rank spearman to examine the relationship of knowledge with PHBS behavior obtained $p$ value 0.792 (above 0.05 ). It was concluded that there was no relationship between knowledge with PHBS behavior in housewives; and the results of statistical tests to examine the relationship of attitude to PHBS behavior obtained $\mathrm{p}$ value 0.007 (below 0.05). It was concluded that there was a relationship between attitudes and PHBS behavior in housewives

\section{DISCUSSION}

\section{Knowledge PHBS}

Most housewives have enough PHBS knowledge in the category. The data illustrates that the majority of mothers have sufficient understanding of clean and healthy living behaviors. If peeled out of 10 household indicators the value of knowledge is low in most mothers, namely the benefits of hand washing, consumption of vegetables and fruit, 3M benefits, the impact of smoking and latrines. While in other indicators, housewives already have good knowledge.

Mother's PHBS knowledge in the category is enough due to many factors, one of which is education. Most housewives have high school education. However, the next highest order is dominated by mothers with elementary school education (SD). The level of high school education can be categorized in higher education. By having higher education, 


\section{Journal Of Nursing Practice}

http://thejnp.org

ISSN: 2614-3488 (print); 2614-3496 (online)

Vol.3 No.1. October 2019. Page.33-49

housewives will usually have better knowledge, especially PHBS compared to loweducated mothers. Elementary education is included in low education, where in this level a child does not have a good understanding, so it is more difficult to be able to receive information about something. Although education is not the same as knowledge, however Notoadmodjo(2007) view that education has a close relationship with knowledge. And this education is important as a basis for developing oneself. The higher a person's education, the easier it will be for someone to receive information and develop this information. And knowledge is important in shaping one's actions. From this analysis, it can be said that education contributes to PHBS behavior. Effendy J., (2008) states there is a relationship between education and PHBS. In accordance with Timisela (2007) who found that education level was the dominant factor in PHBS.

Mother's knowledge about PHBS is also influenced by age. Most housewives are 3645 years old. Age 36-45 is a category of mature age, which is very likely to influence the maturity of thinking and determine behavior that is considered better. Age also determines maturity in thinking and acting. In accordance with the (Suriyani, 2009); Gita S.P,etc.(2018), which reveals that age has an influence on clean and healthy lifestyle. Increasing age will make thinking more mature to behave something. Various studies support the opinions of researchers. Iskriyanti (2002) revealed that age will have an influence in the learning process, and become a factor that describes one's social, physical and psychological. The same Harwinta (2008)

which mentions there is a link between age and PHBS. The results of the reinforcement research above are not in line with Wantiyah (2004)

who did not find a meaningful relationship between age and behavior, which is good behavior obtained at a younger age; Maulana (2009) explained that age is a variable that is less correlated with behavior because it is considered more influenced by one's attitude.

Sufficient knowledge is also influenced by work factors. Most of them are housewives. This profession is very possible to have a limited community environment, and allegedly has limited information as well. The community is limited, and the frequency is more at home than outside the home, making researchers believe that the information obtained is also limited. Sesuai dengan Notoatmodjo (2010) which states that the work environment contributes to experience and knowledge. Nevertheless a housewife can be said to be someone who has more exposure in 10 indicators compared to other family members. However, it cannot be said that someone who is exposed to more with various PHBS activities will have good knowledge. High exposure has an impact on experience in these behaviors.

Sufficient knowledge is also influenced by the availability of media in the household. Half of the respondents $(51.2 \%)$ have 2 media, namely television and handphone (cellphone). If seen from the ownership of these 2 media, it allows respondents to be able to find more information about PHBS. Also included in this PHBS. Housewives can actually get a variety of healthy information from the media they have at home. Various media can be used to find information in a broad scope, namely radio, television, magazines and newspapers and the internet. However, this researcher's opinion needs to be reviewed by looking at the interest in the show / type of spectacle for housewives. The interest in health information through the media, will more or less have a good impact on the knowledge of housewives. Rahayu (2010) mentioning that interest is a form of one's interest in something. If interest about something, is not in someone, it will become a barrier for someone to get information, especially PHBS. 


\section{PHBS attitude}

Most housewives have a good attitude about PHBS. This data shows that the majority of mothers already have a good understanding of PHBS, so that this understanding forms a good attitude / perception about PHBS. Respondents showed good attitude and supported from 10 indicators. From the percentage of mothers with more than $70 \%$ of mothers having a good attitude on each PHBS indicator. The results of this study are in accordance with Azrimaidaliza, Karina,N., (2012) who also found that most RT mothers had a good attitude about PHBS. Research Timisela (2007)) found attitude as the dominant factor in the formation of PHBS. As well as Zahara (2001); (Yaslina, Y., etc. 2018) who also found a positive association with maternal PHBS in family settings. Another study revealed that there was a relationship between family characteristics, knowledge of the family head, attitudes of the head of the family, utilization of information services and health services for PHBS RT applied with PHBS RT (Khairiyati, L., Rahman, F., Udin, A., \& Anhar, 2019). From this kind attitude, ideally it should also form good behavior. Support theory from Notoatmodjo (2012) yang menyampaikan bahwa sikap mewujukan suatu bentuk perilaku.

Positive attitudes about maternal PHBS are in a good category, due to one of them experiences. The experience of housewives here, which is meant is the experience of mothers in doing 10 indicators. Researchers think that Mother supports positively in carrying out 10 PHBS indicators is possible because various PHBS activities have long been run and can be said to be the results of education from mother's parents when they were small. So that it appears as a daily habit. Because it has become a habit, it will be more inclined to have a positive attitude about this PHBS. Attitude is a response to a stimulus that appears. This attitude cannot be seen directly, but also determines the formation of behavior. Notoatmodjo (2010) argues that attitude as a closed reaction (can be positive / negative) to a stimulus, which cannot be seen directly but can be interpreted from closed behavior.

\section{BEHAVIOR}

Most housewives have good behavior about PHBS. This data shows that the majority of mothers have implemented 10 PHBS indicators. If examined from each indicator, it is known that out of the 10 indicators only 5 indicators meet the average value, which is above $70 \%$ of mothers doing the activity. The five indicators are labor assisted by medical personnel, bringing toddlers once a month to posyandu, giving exclusive breastfeeding, washing hands before and after activities, and using clean water for household needs. While the other indicators are still below $70 \%$ of mothers who do it. means that there is still homework that must be completed in the household setting in the study.

PHBS must always be done in the household setting. Given that by carrying out this PHBS action although it is considered trivial but has a big impact on the health of the self and the surrounding community. Of the 10 indicators there are several indicators that are risky if not done will cause infectious diseases.

Dinkes (2009), states that there are several indicators that play a role in the spread of infectious diseases caused by climate change namely "using clean water, washing hands with soap and clean water, using healthy toilets, removing larvae at home once a week.

The clean and healthy behavior of good housewives in the household is one of the health determinants. With housewives implementing indicators specifically indicators that allow the transmission of disease, the incidence of diarrhea, dengue fever which often occurs in the data community is minimized. Opinion of this researcher agrees with Dinkes (2009); 


\section{Journal Of Nursing Practice}

http://thejnp.org

ISSN: 2614-3488 (print); 2614-3496 (online)

Vol.3 No.1. October 2019. Page.33-49

Raksanagara (2015) which revealed that with the mother doing the PHBS indicator related to infectious diseases, various seasonal diseases that occur would be reduced. He also said that the incidence of dengue fever would be lower, and diarrhea if maternal PHB increased. Behavior and environment as the main factors detreminan infectious diseases. The results also showed that there was a correlation between clean and healthy living behavior with the incidence of diarrhea $(r=-0.70)$, free numbers of larvae $(r=-0,600$ and dengue fever $(r$ $=-0,20)$.

\section{RELATIONSHIP OF KNOWLEDGE, ATTITUDE WITH CLEAN AND HEALTHY BEHAVIOR}

Bivariate tests show that there is no relationship between knowledge and PHBS and there is a relationship between attitudes and PHBS of housewives. This data shows that in this study PHBS was not related to knowledge. The researcher believes that knowledge is not the dominant factor that influences PHBS. The results of this study contradict the theory which reveals that knowledge plays an important role in the formation of PHBS. Notoatmodjo, (2012) said that knowledge is the key to behavior, and also knowledge as a result of learning from one's sensory observations. The incompatibility of the results of the research with the theory is possible because the respondents in knowing the PHBS are still in the stage of knowing they have not yet reached the stage of understanding "why this behavior should be done" so that it has not impacted the behavior of housewives. The researcher also believes that the behavior of clean and healthy living by housewives is possible to be a hereditary routine. This routine makes housewives undergo 10 indicators but have not arrived at the application stage. Notoatmodjo (2010) that knowledge is the key to behavior, and also knowledge as a result of learning from one's sensory observations. The incompatibility of the results of the research with the theory is possible because the respondents in knowing the PHBS are still in the stage of knowing they have not yet reached the stage of understanding "why this behavior should be done" so that it has not impacted the behavior of housewives. The researcher also believes that the behavior of clean and healthy living by housewives is possible to be a hereditary routine. This routine makes housewives undergo 10 indicators but have not arrived at the application stage.

He also said that the level of knowledge from the stage of know, understand, application, analysis, synthesis and evaluation of PHBS. Researchers argue that someone will experience behavioral changes if they have a minimum level of knowledge of "understanding" level. Someone who has knowledge, may not be able to apply it in behavior if there is no understanding stage. If studied from the level of education, respondents who have knowledge of the less category come from mothers who have elementary education level. In theory, the results of this study are appropriate, because this knowledge is the result of learning through the five senses. With low education, the mother has not yet been able to fully understand the information obtained. The higher education someone will be able to understand and develop information well. In addition there are also many factors that affect knowledge, which will have an impact on PHBS. Wawan, A dan Dewi (2010)

revealed the age, education, social culture and environment also formed PHBS. Clean and Healthy Life Behavior (PHBS) is a group of behaviors as learning outcomes so that it has an impact on the ability to help themselves and their families in the health field(Depkes, 2006). The results of this study are in line with Saibaka, Y.E., Tucuman, AAT., Rumayar, (2016) who examined the Relationship Between Knowledge and Attitudes with Household 


\section{Journal Of Nursing Practice}

http://thejnp.org

ISSN: 2614-3488 (print); 2614-3496 (online)

Vol.3 No.1. October 2019. Page.33-49

PHBS in Pusksesmas Wawonasa, Manado City, with the results there was no relationship between knowledge and PHBS ( $p$ value 0.916). The results of this study contradict the research which found that there was a relationship between knowledge and attitudes with the implementation of PHBS in the household, namely in the study Suriyani (2009); Artini (2010); Azrimaidaliza, Karina,N.(2012); (R. Damayanti, etc. 2017); Tumiwa (2015).

The results of statistical tests also show that there is a relationship between attitudes and PHBS. This data shows that attitudes are more dominant in influencing clean and healthy behavior. Attitude is said to be a response to an event. Someone will be healthy, if you have minimal knowledge at the stage of understanding the importance of something done. So here, researchers believe that attitudes are a determinant of whether or not a behavior is carried out, including in a clean and healthy lifestyle. Including in conducting an assessment of something especially in matters relating to health. Agree with Ramdaniati (2008) which states that attitude is related to PHBS. Becker also argued that attitude as one of the domains in health behavior. As an opinion / assessment in relation to health care, attitudes to infectious and non-infectious diseases or other factors that affect human health, as well as attitudes to various existing health service facilities.

The results of the statistical tests contradict some of the results of the research, namely Azrimaidaliza, Karina,N., (2012) who found a connection of knowledge, attitudes with the implementation of PHBS mothers in households. This study also produced information that most RT mothers had a good attitude about PHBS. Likewise with Kusumawati, Y., Astuti, D., (2008) also explained that there was a relationship between environmental health knowledge and clean and healthy lifestyle. Likewise with Resminawati (2010) which explains the relationship between the knowledge of the head of the family and the PHBS of the head of the family but this is not in accordance with the results of the research of a well-informed mother who will have an impact on the PHBS behavior that is lacking

\section{CONCLUSION}

The application of clean and healthy lifestyle is not related to knowledge, but is related to the attitude of housewives in RT 03 RW 06 Tlogomas Malang.

\section{REFERENCES}

Artini, N. N. (2010). Hubungan Pengetahuan Dan Sikap Orang Tua Bayi Dengan Penerapan Perilaku Hidup Bersih Dan Sehat Di Puskesmas Pasundan Samarinda Kalimantan Timur. Retrieved from shttp://eprints.uns.ac.id/2910/1/ 175391901201110001. pdf

Azrimaidaliza, Karina,N., E. (2012). Pengetahuan dan Sikap Ibu Mengenai Perilaku Hidup Bersih dan Sehat di Kelurahan Koto Lalang. Jurnal Kesehatan Masyarakat Andalas) (Andalas Journal of Public Health, 1(2). Retrieved from http://jurnal.fkm.unand.ac.id/index.php/jkma/article/view/100

Depkes, R. (2006). Perilaku Hidup Bersih dan Sehat di Rumah Tangga. Jakarta: Depkes,RI.

Dinas Kesehatan Lumajang. (2015). Laporan Hasil Survey Rumah Tangga Sehat Kabupaten Lumajang Tahun 2015. Lumajang.

Dinkes. (2009). Perilaku Hidup Bersih dan Sehat. Bandung Jawa Barat.

Effendy J., dkk. (2008). Analisis Perilaku Hidup Bersih dan Sehat Pada tatanan Rumah tangga di Kabupaten Lombok tengah Tahun 2008. Retrieved from 


\section{Journal Of Nursing Practice}

http://thejnp.org

ISSN: 2614-3488 (print); 2614-3496 (online)

Vol.3 No.1. October 2019. Page.33-49

http;//simkes.fk.ugm.ac.id/category/tesis/.

Gita Sekar Prihanti, Lista D. A., Habibi R, Arsinta I. I., Hanggara S. P., Galih R. P., S. F. (2018). Faktor-faktor yang Mempengaruhi Tingkat Perilaku Hidup bersih dan Sehat Pada tataan Rumah tangga di Wilayah Kerja Puskesmas Poned X. Jurnal Ilmu Kesehatan Dan Kedokteran Keluarga, 14(1). https://doi.org/https://doi.org/10.22219/sm.Vol14.SMUMM1.6644 | Abstract views: 466 | PDF views : 2259

Harwinta. (2008). Faktor - Faktor Yang Mempengaruhi Tingkat Perilaku Hidup Bersih Dan Sehat (PHBS) Tatanan Rumah Tangga Dilokasi Proyek Kesehatan Keluarga Dan Gizi (KKG) Kebupaten Tapanuli Selatan 2004. Tesis Program Studi Magister Administrasi dan Kebijakan Kesehatan Universitas Sumatra Utara.

Hidayat, TS dan Faudia, N. (2011). Hubungan Sanitasi Lingkungan, Morbiditas dan Status Gizi Balita di Indonesia. Jurnal Lingkungan, Mordibitas, Dan Status Gizi. PGM, 34(2), 104-113. Retrieved from https://ojs.unud.ac.id/index.php/psikologi/article/view/25052/16268

Indonesia, K. K. R. (2014). Profil kesehatan Indonesia. Jakarta: Kemenkes RI.

Iskriyanti, H. (2002). Hubungan Karakteristik, Pengetahuan dan Sikap Ibu Rumah Tangga Tentang PHBS Dengan Praktek Kesehatan Keluarga dan Kesehatan Lingkungan di Kelurahan Rejowinangun Kecamatan Kota Gede Kota Yogyakarta. Retrieved from eprints.undip.ac.id/28232/1/1500.pdf

Kemenkes. (2018). Data dan Informasi Profil Kesehatan Indonesia. Retrieved from http://www.depkes.go.id/resources/download/pusdatin/profil-kesehatanindonesia/Data-dan-Informasi_Profil-Kesehatan-Indonesia-2018.pdf

Khairiyati, L., Rahman, F., Udin, A., \& Anhar, V. Y. (2019). Factors Affecting the Implementation of Clean and Healthy Living Behavior at Household Level (Observational Study at Sungai Paring Village, Martapura Kota District). Indian Journal of Public Health Research \& Development, 10(4), 529, 10(4), 529. Retrieved from

http://eresources.perpusnas.go.id:2124/login.aspx?direct=true $\& \mathrm{db}=\mathrm{edb} \& \mathrm{AN}=135869546 \&$ si te $=$ eds-live)

Kusumawati, Y., Astuti, D., A. (2008). Hubungan antara Pendidikan dan Pengetahuan Kepala Keluarga tentang Kesehatan Lingkungan dengan Perilaku Hidup Bersih dan Sehat (PHBS). Jurnal Kesehatan Masyarakat, 1(1).

Maulana, H. (2009). Promosi Kesehatan. Jakarta: EGC.

Notoatmodjo, S. (2010). Promosi Kesehatan dan Perilaku Kesehatan. Jakarta: Rineka Cipta.

Notoatmodjo, S. (2012). Promosi Kesehatan dan Perilaku Kesehatan. Jakarta: Rineka Cipta. https://doi.org/10.1017/CBO9781107415324.004

Putri,KAK., Sudhana, H. (2013). Perbedaan Tingkat stress Pada Ibu Rumah Tangga Yang Menggunakan dan Tidak menggunakan Pembantu Rumah tangga. Jurnal Psikologi, 1(1), 94-105. Retrieved from https://ojs.unud.ac.id/index.php/psikologi/article/view/25052/16268

R. Damayanti, Z. Shaluhiyah, and K. C. (2017). Peningkatan Pengetahuan dan Sikap Ibu Tentang PHBS Tatanan Rumah Tangga (ASI Eksklusif) Di Kabupaten Sambas melalui Media Leaflet Berbahasa Daerah. Jurnal Promosi Kesehatan Indonesia, 12(1), 1-12. Retrieved from https://doi.org/10.14710/jpki.12.1.1-12

Rahayu, S. . (2010). Pengantar kebijakan Fiskal. Jakarta: Bumi Aksara.

Rahmawati, E. P. A. (2012). Perilaku Hidup Bersih dan Sehat (PHBS). Yogyakarta: Nuha 
Medika.

Raksanagara, A. (2015). Perilaku Hidup Bersih dan Sehat Sebagai Determinan Kesehatan Penting Pada Tatanan Rumah Tangga di Kota Bandung. JSK, 1(1).

Ramdaniati, N. E. (2008). Pengetahuan dan sikap terhadap perilaku hidup bersih dan sehat pada ibu rumah tangga RW 04 kelurahan Manggarai Jakarta Selatan. Retrieved from http://lib.ui.ac.id/file?file=pdf/abstrak/id_abstrak-122651.pdf

Saibaka, Y.E., Tucuman, AAT., Rumayar, A. A. (2016). Hubungan Antara pengetahuan Dan Sikap D. Puskesmas Wawonasa Kota Manado. Jurnal IKMAS, 1(3). Retrieved from http://ejournalhealth.com/index.php/ikmas/article/view/78/76

Suriyani. (2009). Faktor-Faktor Yang Mempengaruhi Pelaksanaan Program Promosi Kesehatan Rumah Tangga Yang Bersih Dan Sehat Di Wilayah Kerja Puskesmas Teladan Medan Kecamatan Medan Kota (Online). Retrieved from http://repository.usu.ac.id/bitstr eam/123456789/6871/1/09E01 944

Timisela, A. (2007). Pengetahuan, sikap dan perilaku hidup bersih dan sehat pada karyawan Dinas Kesehatan Propinsi Papua.

Tumiwa, F. f. (2015). Hubungan Antara faktor Predisposing, enabling, dan Reinforcing dengan perilaku hidup bersih dan sehat tatanan rumah tangga di kecamatan remboken kabupaten minahasa, (Online). Retrieved from http://jkesmasfkm.unsrat.ac.id/wpcontent/uploads/2015/06/1-FIX-FINI-TUMIWA.pdf

Wantiyah. (2004). Gambaran Perilaku Hidup Bersih dan Sehat (PHBS) Di Rw IV Kelurahan Terban Wilayah Kerja Puskesmas Gondosuman II Yogyakarta. Program Studi Ilmu Keperawatan Fakultas Kedokteran UGM.

Wawan, A dan Dewi, M. (2010). Teori dan Pengukuran Pengetahuan, Sikap dan Perilaku Manusia. Yogyakarta: Nuha Medika.

Yaslina, Y., Andini, B., \& Nofriadi, N. (2018). HUBUNGAN SIKAP DAN MOTIVASI DENGAN PENERAPAN PERILAKU HIDUP BERSIH DAN SEHAT (PHBS)PADA KELUARGA DI WILAYAH KERJA PUSKESMAS GULAI BANCAH KOTA BUKITTINGGI TAHUN 2018. JURNAL KESEHATAN PERINTIS (Perintis's Health Journal), 1(65-72). Retrieved from https://doi.org/10.33653/jkp.v5i1.97 